\title{
PELESTARIAN TRADISI “MEKOTEK” DESA ADAT MUNGGU
}

\author{
I Wayan Rasna ${ }^{1}$, Ni Made Emy Juniartini ${ }^{1 *}$ \\ ${ }^{1}$ Universitas Pendidikan Ganesha, Indonesia \\ *e-mail: emyjuniartini55@gmail.com
}

\begin{abstract}
Abstrak
Tradisi adalah kebiasaan yang lahir secara turun-temurun dari suatu daerah pada suatu tempat yang selalu diperingati dan dilaksanakan sesuai dengan adat dan kebiasaan di daerah tersebut. Bali mempunyai beragam tradisi yang masih dilaksanakan sampai saat ini, salah satunya yaitu tradisi mekotek. Adapun penelitian ini memiliki tujuan yaitu untuk mendeskripsikan tradisi "mekotek" di Desa Adat Munggu, menganalisis nilai yang ada dalam tradisi "mekotek" di Desa Adat Munggu, dan menjelaskan bagaimana pelestarian tradisi "mekotek" di Desa Adat Munggu. Penelitian ini menggunakan penelitian kualitatif dengan metode deskriptif. Subjek yang dilakukan pada penelitian ini yaitu masyarakat di desa Adat Munggu. Objek penelitian yang digunakan yaitu desa Adat Munggu. Adapun teknik pengumpulan datanya terdiri dari teknik observasi, teknik wawancara dan teknik dokumentasi. Hasil yang diperoleh dalam penelitian ini menunjukkan bahwa tradisi "mekotek" di Desa Adat Munggu merupakan kebiasaan yang diwariskan dari generasi sebelumnya ke generasi berikutnya secara turun-temurun, yang mencakup berbagai nilai budaya. Nilai-nilai yang terdapat pada tradisi "mekotek" mengandung nilai-nilai positif yang sangat besar bagi masyarakat Munggu, nilai-nilai tersebut yaitu nilai sosial, nilai budaya, nilai religius dan nilai kebersamaan. Pelestarian tradisi di Desa Adat Munggu masih dilestarikan sampai saat ini dan menjadi tantangan bagi masyarakat Munggu, dimana masyarakatnya harus dapat mempertahankan warisan budaya dari leluhur terdahulu sehingga tradisi ini tidak punah.
\end{abstract}

Kata kunci: Pelestarian Budaya; Tradisi Mekotek; Desa Adat

\begin{abstract}
This tradition is a habit that is born from generation to generation from an area in a place that is always commemorated and implemented following the customs and habits of the area. Bali has various traditions that are still being carried out today, one of which is the "mekotek" tradition. The objectives of this research are to describe the "mekotek" tradition in the Munggu traditional village, to analyze the values that exist in the "mekotek" tradition in the Munggu traditional village, to explain how to preserve the "mekotek" tradition in the Munggu traditional village. This research uses qualitative research with descriptive methods. The subjects in this study were the people in the Munggu traditional village. The research object used was the Munggu traditional village. The data collection techniques consist of observation techniques, interview techniques, and documentation techniques. The results obtained in this study indicate that the "mekotek" tradition in the Munggu traditional village is a habit passed down from previous generations to the next generation from generation to generation, which includes various cultural values. The values in the "mekotek" tradition contain tremendous positive values for the Munggu people: social, cultural, religious, and togetherness. The preservation of traditions in the Munggu traditional village is still preserved today and is a challenge for the Munggu community, where the community must maintain the cultural heritage of their previous ancestors so that this tradition does not become extinct.
\end{abstract}

Key words: Culture Preservation; Mekotek Tradition; Traditional Village

This is an open access article under the CC BY-SA license.

Copyright (C 2021 by Author. Published by Universitas Pendidikan Ganesha.

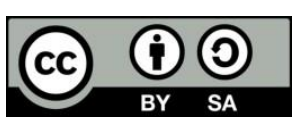

\section{PENDAHULUAN}

Budaya berasal dari bahasa sansekerta yaitu "buddhaya" yang artinya budhi atau akal. Menurut Koentjaraningrat,
(2009) Dalam ilmu antropologi disebutkan bahwa kebudayaan adalah keseluruhan dari pemikiran, tindakan, dan sistem, juga hasil kerja manusia dalam kehidupan 
bermasyarakat. Pengetahuan ini menjadi miliknya melalui pembelajaran. Menurut Rafael Raga Maran (2007) budaya manusia telah meninggalkan jejaknya di panggung sejarah. Terlepas dari ragam bentuk dan bentuknya, setiap negara di dunia memiliki budaya. Kebudayaan merupakan hasil dari aktivitas manusia yang terus menerus dan telah melahirkan suatu adat atau kebiasaan. Selain itu, adat atau kebiasaan ini menjadi tradisi. Sejalan dengan (Depdikbud, 1990) yang menyatakan bahwa tradisi adalah suatu adat atau kebiasaan yang diwariskan secara turun-temurun, yang memuat berbagai nilai budaya berupa sistem kepercayaan dan adat istiadat

Bali mempunyai warisan budaya dari leluhur yang melimpah yang masih ditanamkan pada kebiasaan dalam kehidupan sosial masyarakat bali. Kebiasaan unik tersebut masih tertanam dan terlaksana dengan baik yang dikarenakan desa pekraman selalu konsisten untuk tetap menjaga kepercayaan dan keyakinan masyarakatnya, serta menerapkan segala peraturan adat. Serta, adanya peran sosial masyarakat Hindu di Bali untuk melaksanakan kegiatan keagamaan dengan rutin sehingga tradisi-tradisi tersebut masih ada sampai sekarang. Disamping itu, terbitnya undang-undang nomor 25 tahun 1999 serta undang-undang nomor 32 tahun 2004 pada dasarnya membuka kesempatan dan peluang yang baru untuk membangkitkan kembali budaya- budaya lokal, yang terwujud dalam semangat lokalitas, dan peningkatan harga diri dan martabat komunitas lokal serta tetap mempertahankan keberagaman yang semakin berkembang.

Sampai sekarang, Bali masih kuat mempertahankan tradisi ritualnya karena diyakini bahwa tradisi ritual tersebut masih mampu menjadi mediator antara hubungan antara manusia dengan manusia (pawongan), manusia dengan Tuhan (parahyangan), dan manusia dengan lingkungan (palemahan) yang disebut dengan istilah Tri Hita Karana sebagai konsepsi kebudayaan, terimplementasi dalam kehidupan sosial masyarakat desa adat (Triguna, 2000). Selain itu, adanya nilai religius masuk dalam pelaksanaannya, apabila tradisi tersebut tidak dilaksanakan dipercaya akan menimbulkan suatu bencana di alam semesta (Bhuwana Agung) dan badan manusia (Bhuwana Alit).
Beragam tradisi yang dimiliki masyarakat bali, keberadaannya masih dijaga kelestariannya hingga sekarang, salah satunya adalah tradisi mekotek yang dilaksanakan secara rutin yaitu setiap 6 bulan sekali yang berlangsung 10 hari setelah hari raya Kuningan. Tradisi mekotek hanya ada dan dilaksanakan di desa Munggu. Upacara mekotek juga dikenal dengan istilah ngerebek, dan tujuan dilaksanakannya upacara ini adalah untuk memohon keselamatan agar terhindar dari wabah penyakit atau bahaya lainnya di desa munggu. Pada pelaksanaannya ada beberapa pantangan yang harus dipatuhi, yaitu bagi peserta yang sedang cuntaka tidak diperbolehkan untuk turut serta dalam pelaksanaan mekotek.

Tradisi mekotek juga memiliki ketertarikan tersendiri, yaitu di dalam pelaksanaannya tidak mengenal batas usia maupun golongan. Di samping itu, peralatan yang digunakan dalam pelaksanaan tradisi mekotek menggunakan alat berupa tombak, akan tetapi saat ini sudah diganti dengan kayu pulet untuk mencegah terjadinya kecelakaan pada saat pelaksanaan mekotek berlangsung. Hal ini membuktikan bahwa terjadinya akulturasi budaya yang membentuk suatu pembaharuan akan tetapi masih membawa serta sebagian warisan budaya lama yang memiliki fungsi sebagai ciri identitas yang berlanjut (Sedyawati, 2007). Berbagai macam tradisi yang terintegrasi dalam bentuk pelaksanaan upacara-upacara tradisional di Bali, serta keunikannya yang dapat dilihat dari pelaksanaan tradisi tersebut, mendorong urgensi untuk dilakukan suatu pengkajian, terutama terhadap beragam tradisi-tradisi yang masih dipertahankan oleh masyarakat Bali pada umumnya. Dengan demikian, tujuan dari penelitian ini adalah ingin mengkaji secara mendalam tentang tradisi mekotek yang ada di Desa Adat Munggu serta nilai-nilai yang terdapat di dalam tradisi mekotek tersebut dan pelestarian dari tradisi mekotek.

\section{METODE}

Penelitian ini merupakan penelitian kualitatif dengan metode deskriptif. Menurut Moleong (2019: 6) Penelitian kualitatif merupakan penelitian yang bertujuan mendeskripsikan fenomena yang dialami oleh objek penelitian dalam bentuk kata dan bahasa. Subjek penelitian ini yaitu 
masyarakat Desa Adat Munggu. Objek penelitian yaitu Desa Munggu Kecamatan Mengwi Kabupaten Badung. Metode yang digunakan yaitu metode analisis deskriptif kualitatif yaitu dengan mengumpulkan berbagai sumber yang relevan dan membahas secara deskriptif berdasarkan hasil pengamatan (observasi), wawancara, dan dokumentasi. Teknik pengumpulan data menggunakan teknik observasi, wawancara dan dokumentasi. Teknik observasi adalah suatu cara memperoleh data dengan mengadakan "pengamatan dan pencatatan" secara sistematis tentang tradisi mekotek di Desa Adat Munggu. Teknik wawancara merupakan percakapan dengan tujuan untuk memperoleh data yang terjadi mengenai tradisi mekotek di Desa Adat Munggu. Serta, dokumentasi yang digunakan oleh penulis adalah foto-foto sebagai penunjang data observasi.

\section{HASIL DAN PEMBAHASAN Tradisi Mekotek}

Penelitian Menurut Agustina Putri (2013) tradisi mekotek dilaksanakan hingga saat ini untuk menyambut prajurit Kerajaan Mengwi yang berhasil meraih kemenangan atas melawan Kerajaan Blambangan. Tahun 1915 pada masa pemerintahan Belanda, tradisi mekotek sempat dihentikan oleh pihak Belanda karena khawatir akan terjadinya sebuah pemberontakan. Namun, setelah dihentikannya tradisi mekotek terjadi wabah penyakit dan semua hasil panen masyarkat Munggu gagal panen. Sehingga tradisi mekotek dilaksanakan lagi untuk tolak bala atau menghindari musibah tersebut.

Tradisi ngerebeg atau mekotek Desa Adat Munggu, Kecamatan Mengwi Badung Bali adalah warisan budaya pada masa kejayaan Kerajaan Mengwi yang mempuyai wilayah di Jawa Timur. Ngerebeg dilakukan setiap 6 bulan sekali yaitu setiap Saniscara Wuku Kuningan, pada hari sabtu yang bertepatan dengan hari Raya Kuningan.

Tradisi mekotek sendiri dilakukan sampai sekarang karena masyarakat munggu mempercayai jika tidak melakukan tradisi ini akan menimbulkan wabah bagi waga Desa
Adat Munggu. Oleh sebab itu tradisi ini dilakukan untuk menghindarkan dari wabah tersebut dengan maksud memohon kepada Ida Sag Hyang Widhi Wasa supaya menghindarkan wabah yang ditakutkan oleh waga setempat tidak terjadi lagi di kampung Desa Munggu sendiri. peserta dalam tradisi ini bisa dilakukan oleh dari remaja hingga orang tua. Dalam melaksanakan tradisi mekotek ada beberapa persyaratan bagi peserta mekotek yakni tidak diperkenankan melakukan tradisi ini jika anggota keluarga dari peserta tersebut ada yang meninggal atau istrinya melahirkan.

Sebelum dilaksanakannya kegiatan mekotek, peserta mekotek harus mempersiapkan peralatan berupa kayu pulet yang panjangnya kurang lebih 2,5 meter, berisi jejaitan tamiang, dan daun pandan berduri. Pakaian yang digunakan oleh peserta mekotek yaitu pakaian adat madya, sedangkan para pengiring menggunakan pakaian adat kepura dengan membawa benda-benda pustaka suci, seperti: canang, tedung, tameng, tombak, dan banten. Kegiatan tradisi mekotek dilaksanakan mulai dari pukul 14.00-16.00 wita. Pertama, para peserta dan pengiring menuju ke pura Puseh dan pura dalem untuk melaksanakan persembahyangan. Setelah selesai di pura Puseh dan Desa, peserta dan pengiring menuju Pura Dalem Wisesa, dan mengelilingi Desa Adat Munggu. Kemudian berakhir kembali di Pura Puseh dan Desa. Pada perjalanan melewati Pura Khayangan Tiga peserta mekotek selalu diperciki tirta oleh para Mangku Pura Khayangan Tiga yang bermakna sebagai keselamatan dan ketentraman. Masyarakat Desa Adat Munggu beramai-ramai berjalan mengelilingi wilayah Desa Munggu diiringi gamelan balaganjur dan nyanyian-nyanyian kidung dan diakhiri dengan menabrakan kayu pulet yang dibawa dan kemudian disatukan menjadi bentuk gunung. Hal tersebut juga menjadi alasan mengapa tradisi ini disebut mekotek, yaitu karena adanya bunyi tek..tek..tek yang ditimbulkan dari kayu yang disatukan. Gambar 1 merupakan foto dari pelaksanaan tradisi mekotek yang dilaksanakan di desa Munggu. 


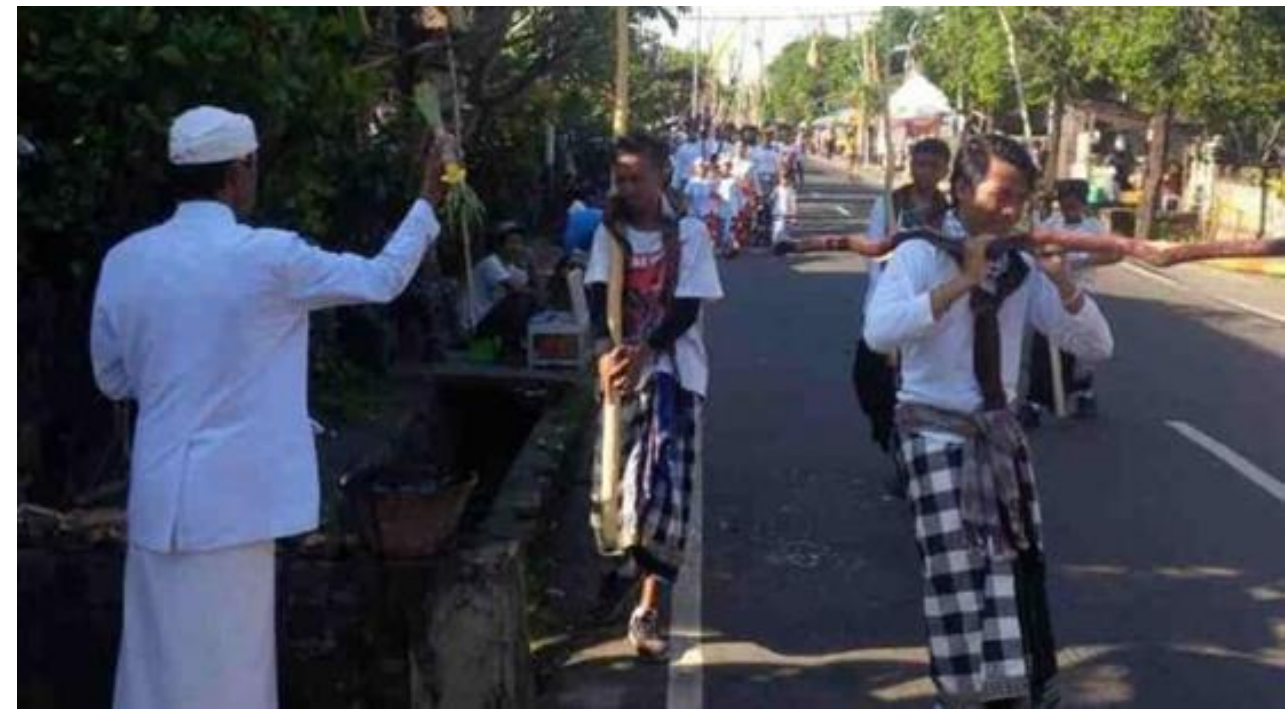

Gambar 1. Para peserta dipercikan air suci (tirta)

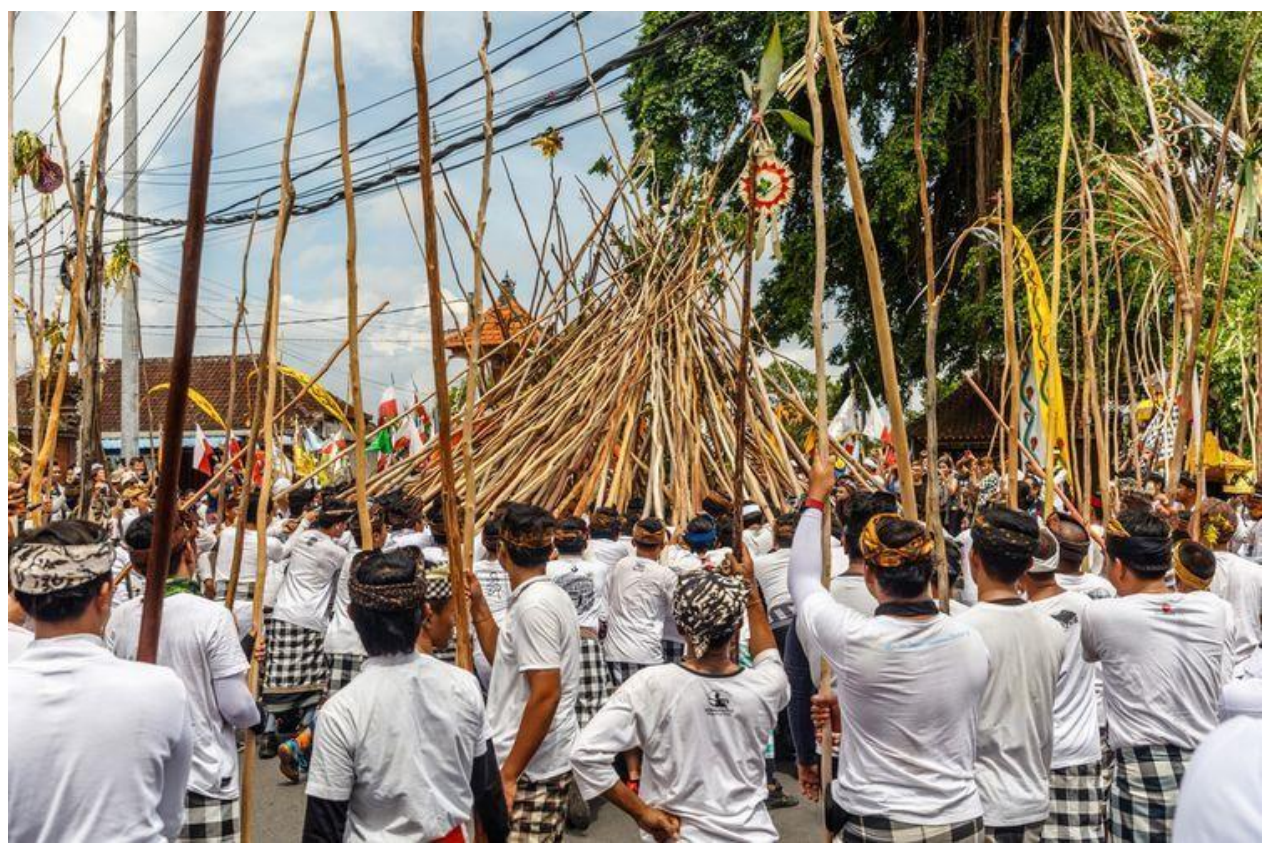

Gambar 2. Pelaksanaan Tradisi Mekotek

\section{Nilai-Nilai yang Terkandung dalam Tradisi Mekotek}

Tradisi mekotek mengandung berbagai macam nilai yang dikaji menggunakan kajian etnopedagogi. Hal ini dikarenakan nilai yang terkandung di dalam tradisi mekotek merupakan kearifan lokal pembentuk etnopedagogi. Etnopedagogi sendiri memiliki pengertian pendidikan yang didasari oleh etnografis (kearifan lokal) yang penting untuk dilaksanakan yang bertujuan untuk membangun dan mewariskan nilai-nilai budaya lokal Yogi Yogaswara,dkk (2017). Sebagai suatu tradisi yang tumbuh dan hidup dalam masyarakat, tentu memiliki nilai-nilai yang terkandung dalam tradisi tersebut, sehingga mampu dipertahankan oleh masyarakat.

\section{Nilai Sosial}

Menurut Hamzah (2019) Nilai sosial merupakan pelajaran yang dapat dipetik dari 
perilaku dan tata cara kehidupan sosial masyarakat. Perilaku sosial adalah perilaku individu dalam lingkungannya terhadap peristiwa yang berkaitan dengan orang lain, cara berpikir, dan hubungan sosial antar individu.

Menurut Agustina Putri (2013) nilai sosial dalam tradisi mekotek di desa Adat Munggu yaitu dengan mengedepankan unsur persatuan dan kebersamaan yang dapat dilihat dalam pelaksanaan tradisi ini, maka nilai sosial antar warga desa Adat Munggu sangat baik. Semua warga desa Adat Munggu dapat melakukan tradisi mekotek atau ngerebeg tanpa memandang usia atau golongan. Nilai sosial yang dapat diambil dari tradisi ini juga adanya sikap rela berkorban dilihat dari seluruh warga yang rela mengorbankan diri dan waktunya demi kepentingan bersama, kemudian terdapat unsur kekeluargaan dan gotong-royong yang dilihat dari sifat-sifat manusia yang mampu mengurangi egonya masing-masing dan sifat induvidualisme yang juga ada dari manusia yang juga mampu mengendalikan diri, serta tidak mudah tersinggung, maupun dihasut orang lain yang dapat menimbulkan konflik. Hal ini bisa didapatkan saat proses pelaksanaan mekotek ketika kayu terjatuh kemudian saat disatukan, ada salah satu peserta yang tertimpa tetap tenang dan tidak memiliki rasa marah maupun dendam.

Nilai Budaya

Nilai budaya memiliki konsepsikonsepsi yang ada di alam pikiran masyarakat mengenai hal-hal yang dianggap mulia Koentjaraningrat (1990). Nilai dan norma budaya adalah konsep yang ditemukan dipikiran orang tentang budaya seperti apa yang menurut mereka baik atau buruk. Oleh karena itu nilai dan norma budaya bukanlah gagasan pribadi, tetapi nilai dan norma adalah gagasan anggota masyarakat. Terdapat sistem bersama (sharing system) dalam masyarakat untuk menentukan nilai dan norma yang muncul dalam adat dan budaya dalam masyarakat Robert Sibarani (2012).

Nilai budaya dalam tradisi ngerebeg atau mekotek dapat menambah pengetahuan tentang sejarah budaya mekotek dan memiliki rasa tanggung jawab yang tinggi kepada seluruh masyarakat Desa Adat Munggu dalam memelihara dan melestarikan budaya mekotek atau ngerebeg yang menuntut masyarakat Munggu untuk terus melestarikan tradisi ini, sebagaimana yang telah menjadi sebuah tradisi yang menjadi warisan leluhur sebelumnya Agustina Putri (2013).

\section{Nilai Religius}

Menurut Sjarkawi (2009) menyatakan nilai religius adalah nilai yang diturunkan dari kepercayaan kepada seseorang. Nilai religius ini ada dalam bentuk yang bermanfaat dan diimplementasikan oleh setiap orang, dengan patuh dan konsisten untuk melaksanakan ajaran agama yang dianutnya dalam kehidupan sehari-hari

Nilai religius dari tradisi mekotek dapat dirasakan dari unsur magisnya yaitu ketika tradisi mekotek muncul, keberadaan masyarakat Munggu kerauhan/kesurupan. Hal ini sangat diyakinkan oleh masyarakat setempat, jika tradisi ini tidak diikuti akan membuat masyarakat khawatir akan adanya bencana besar, seperti kemarau panjang yang menyebabkan gagal panen, kerusuhan, dan banyaknya warga yang terkena wabah penyakit hingga akhirnya meninggal dunia Agustina Putri (2013).

Nilai religius dalam tradisi mekotek diwujudkan dalam bentuk simbol sebuah peperangan. Salah satunya dapat dilihat dari peralatan pada tradisi tersebut yang berupa tombak yang dibuat oleh kayu pullet. Tradisi mekotek digunakan sebagai salah satu permohonan kepada Ida Sang Hyang Widhi Wasa untuk memperoleh kesuburan, keselamatan dan kesejahteraan.

Nilai Kebersamaan

Menurut Putu Widiasih, dkk (2017)

nilai kebersamaan dapat dilihat dari semangat gotong-royong dan kekeluargaan sangat kental terlihat dalam pelaksanaan tradisi mekotek. Masyarakat desa adat Munggu bekerjasama untuk melaksanakan tradisi ini, mulai dari tahap persiapan sampai dengan selesai. Tradisi ini dilaksanakan secara tulus tanpa mengharapkan imbalan. Nilai kebersamaan pada tradisi mekotek merupakan cerminan dari budaya luhur para nenek moyang yang harus dijadikan panutan secara turun-temurun agar tidak terlena dalam godaan budaya luar yang banyak bertentangan dengan budaya yang diwarikan oleh leluhur terdahulu. Nilai kebersamaan tersebut sangat besar makna dan manfaatnya dalam menjaga persaudaraan, 
kerukunan dan kekeluargaan kehidupan bermasyarakat warga desa adat Munggu.

\section{Pelestarian Tradisi Mekotek di Desa Adat Munggu}

Tradisi mekotek merupakan kegiatan yang dimiliki oleh masyarakat Munggu yang daerahnya terletak di Kecamatan Mengwi Kabupaten Badung yang tanpa disadari sudah menjadi suatu maskot atau ciri khas desa Adat Munggu. Tradisi ini sudah ada sejak zaman dulu yang keberadaannya hingga saat ini masih dapat dijumpai bahkan sudah menjadi sebuah tradisi bagi masyarakat Munggu itu sendiri di dalam melakukan suatu kegiatan baik dalam masyarakat itu sendiri.

Sampai saat ini tradisi mekotek masih tetap berlangsung dan tetap dipertahankan secara turun temurun. Walaupun dalam perjalanannya tradisi ini mengalami perubahan-perubahan, dikarenakan adanya pengaruh kemajuan jaman. Akan tetapi, perubahan-perubahan yang ada tidak mengubah keaslian dan ciri khas dari tradisi mekotek itu sendiri. Hingga saat ini tradisi tersebut masih menggunakan kayu, meskipun tidak semua menggunakan jenis kayu pullet. Dari dulu hingga sekarang, masih banyak warga desa adat Munggu yang ikut serta dalam pelestarian tradisi mekotek. Orang tua bahkan remaja secara sukarela masih ikut serta dan bersemangat menjadi peserta dalam pelaksanaan tradisi ini.

Menurut Widiasih, dkk (2017) beranggapan bahwa makna tradisi mekotek ini tidak akan pernah luntur dari modernisasi jaman. Nilai-nilai yang terdapat pada tradisi mekotek seperti nilai sosial, nilai budaya, nilai religius dan nilai kebersamaan menjadi pondasi kuat untuk melestarikan tradisi mekotek. Dengan menerapkan nilai-nilai tersebut semua masyarakat Munggu akan selalu memiliki sikap gotong-royong untuk menyelesaikan semua pekerjaan yang ada di desa Munggu tersebut tanpa membedakan tinggi rendahnya status sosial seseorang.

Tradisi mekotek ini masih dilestraikan sampai saat ini. Masyarakat Desa Adat Munggu sedikit demi sedikit membangun hubungan yang harmonis antara individuindividu lainnya dengan saling memiliki kepercayaan pada tradisi tersebut dan dampak yang akan ditimbulkan jika tradisi itu tidak dilaksanakan dalam kehidupan di masyarakat. Khususnya bagi masyarakat
Munggu yang menyatakan bahwa adanya tradisi ini merupakan kewajiban bagi masyarakat setempat untuk selalu menyelenggarakan dan melestaraikan guna menjaga keseimbangan, serta menjaga tradisi warisan tersebut. Selain adanya kewajiban pasti adanya hak. Hak yang dapat diterima oleh warga Desa Adat Munggu mengenai pelaksanaan tradisi ini seperti kesejahteraan dan ketentraman, kesuburan dalam bidang pertanian, kesehatan masyarakat, dan menambah akhlak dan budi pekerti yang luhur yang sesuai dengan nilainilai pancasila. Bagi masyarakat setempat tradisi ini selalu dilaksanakan guna menjaga dan melestarikan agar Bhuana agung dan Bhuana alit tetap seimbang. Hal ini, menjadi tantangan bagi masyarakat Munggu untuk tetap menjaga tradisi mekotek. Sehingga, tradisi mekotek dapat dipertahankan pelaksanaannya dan tidak menjadi tradisi yang punah.

\section{SIMPULAN DAN SARAN}

Tradisi mekotek merupakan tradisi yang mengikat kebersamaan warga yang dilakukan secara turun temurun. Selain itu tradisi ini menjadi pemersatu dalam semua kalangan di Desa Adat Munggu, serta menjadi kebanggaan dan rasa syukur masyarakat terhadap kemenangan Kerajaan mengwi dalam peperangan melawan Kerajaan Blambangan. Tradisi mekotek ini mengandung beberapa nilai-nilai seperti nilai sosial, religious, budaya, dan kebersamaan. Nilai sosial dalam tradisi mekotek mengandung unsur-unsur kebersamaan, kekeluargaan, serta gotong-royong dalam pelaksanaan mekotek. Selain nilai-nilai sosial, tradisi ini mengandung nilai budaya yaitu meningkatkan pengetahuan dan wawasan tentang sejarah budaya mekotek, serta tanggung jawab masyarakat desa Adat Munggu untuk memelihara dan melestarikan budayanya. Kemudian, tradisi mekotek mengandung nilai religius seperti adanya kesurupan atau kerauhan didalam pelaksanaanya. Terakhir, tradisi mekotek mengandung nilai kebersamaan, dimana dalam proses tradisi mekotek dari tahap awal hingga akhir masyarakat desa Munggu melaksanakan tradisi tersebut dengan semangat gotong-royongnya. Walaupun jaman sudah semakin modern dengan adanya pengaruh globalisasi, masyarakat Desa Adat Munggu selalu membangun 
hubungan yang harmonis antara individu lainnya dan saling memiliki kepercayaan pada tradisi tersebut, sehingga tradisi mekotek dapat dipertahankan pelaksanaannya dan tidak menjadi tradisi yang punah.

\section{DAFTAR PUSTAKA}

Agustina, P. (2013). Nilai Sosial, Nilai Budaya, Nilai Religius Dalam Tradisi Mekotek Di Desa Adat Munggu, Kecamatan Mengwi, Kabupaten Badung. Skripsi. Universita Pendidikan Ganesha.

Depdikbud. (1994). Fungsi Upacara Tradisional Bagi Masyarakat Pendukungnya Masa Kini. Jakarta: Depdikbud.

Edi, S. (2007). Keindonesiaan Dalam Budaya. Jakarta: Wedatama Widya Sastra.

Hamzah, R. (2016). Nilai-Nilai Kehidupan dalam Resepsi Masyarakat. Cianjur: Pusat Studi Pemberdayaan Informasi Daerah.

Koentjaraningrat. (1990). Pengantar IImu Antropologi. Jakarta: PT Rineka Cipta.

Moleong, L. J. (2019). Metodelogi Penelitian Kualitatif (Edisi Revisi). Bandung: Remaja Karya.

Raga, M. R. (2007). Manusia dan Kebudayaan: Dalam Perspektif IImu Budaya Dasar. Jakarta: Rineka Cipta.

Sabarani, R. (2012). Kearifan Lokal: Hakikat, Peran, dan Metode Tradisi Lisan. Jakarta: ATL.

Sjarkawi. (2009). Pembentukan Karakter Anak. Jakarta: Bumi Aksara.

Triguna, I B. Y. (2000). Teori Tentang Simbol. Denpasar: Widya Dharma.

Widiasih, P., Wesnawa, I G. A., \& Budiarta, I G. (2017). Kajian Pelestarian Tradisi Megibung Di Desa Seraya Tengah, Kecamatan Karangasem, Kabupaten Karangasem (Perspektif Geografi Budaya). Jurnal Pendidikan Geografi Undiksha, 5(3).

Yogaswara. (2017). Tradisi Nyalin Dalam Kehidupan Masyarakat Sunda (kajian struktur dan etnopedagogi). Jurnal Kajian Bahasa, Sastra, dan Bahasa Daerah, 8(2). 